\title{
Endothelium dependent and independent responses in coronary artery disease measured at angioplasty
}

\author{
Diana R Holdright, Debbie Clarke, Philip A Poole-Wilson, Kim Fox, Peter Collins
}

\begin{abstract}
Objective-To investigate the effects of substance $P$ and papaverine, two drugs that increase coronary blood flow by different mechanisms, on vasomotion in stenotic coronary arteries at percutaneous transluminal coronary angioplasty (PTCA).
\end{abstract}

Design-Coronary blood flow responses to substance $P$ and papaverine were measured in stenotic coronary arteries at the time of PTCA with quantitative angiography and a Doppler flow probe. Setting-A cardiothoracic referral centre.

Patients-15 patients undergoing elective PTCA of a discrete epicardial coronary artery stenosis.

Interventions-Pharmacological coronary flow reserve was determined with papaverine 5-10 minutes before and after successful PTCA. Endothelium dependent responses to 2 minute infusions of substance $P\left(10-15 \mathrm{pmol} . \mathrm{min}^{-1}\right)$ were assessed immediately before PTCA.

Main outcome measures-Coronary blood flow responses and changes in epicardial coronary artery area at stenotic, proximal, and distal sites with papaverine and substance $P$.

Results-Stenotic sites dilated with papaverine before PTCA $(17 \cdot 7 \%(6.9 \%)$ (mean (SEM)) area increase, p $<0.05 \mathrm{v}$ baseline). Substance $P$ dilated stenotic sites $(16 \cdot 8 \%(5 \cdot 7 \%)$ area increase, $p<$ $0.05)$ and proximal $(14.3 \%(5.4 \%)$, p < $0.05)$ and distal sites $(41 \cdot 7 \%(9 \cdot 3 \%)$, p $<0.005)$. Coronary flow reserve increased but did not reach normal values after PTCA $(2 \cdot 3(0 \cdot 4)$ before PTCA $v 3 \cdot 0(0 \cdot 4)$ after PTCA, p $<0.05)$ and was associated with an increase in peak flow with papaverine. Angioplasty did not alter baseline flow. After PTCA papaverine caused significant vasoconstriction at the stenotic site $(-13 \cdot 6 \%(4 \cdot 3 \%)$ area decrease, $\mathrm{p}<0.05)$. There was a negative correlation $(r=-0.68, p<0.05)$ between the dilator response with papaverine before PTCA and the constrictor

Conclusions-Substance $P$ causes endothelium dependent dilatation in atheromatous coronary arteries, even at sites of overt atheroma. The cause of the paradoxical constrictor response to papaverine after PTCA is uncertain, but unopposed flow mediated vasoconstriction (the myogenic response) after balloon induced endothelial denudation may be one of several contributory factors.

(Br Heart f 1993;70:35-42)

After angiographically successful percutaneous transluminal coronary angioplasty (PTCA) some patients develop features suggestive of myocardial ischaemia in the absence of restenosis. Myocardial blood supply may be impaired by abnormal coronary vasomotor responses that develop in atheromatous vessels, and may be further altered by the process of PTCA. Studies of coronary flow reserve at the time of PTCA show that balloon angioplasty improves coronary flow reserve immediately after PTCA but this does not necessarily reach normal values. ${ }^{1-3}$ Factors that might account for this include the presence of diffuse atherosclerosis, ${ }^{1}$ coronary microvascular disease,${ }^{4}$ loss of endothelium dependent dilatation, ${ }^{5}$ release of vasoconstrictor agents from platelets and the vessel wall, ${ }^{6}$ distal embolisation of microthrombi, ${ }^{7}$ the stimulation of stretch dependent endothelium independent myogenic tone, ${ }^{8}$ altered arachidonate metabolism, ${ }^{9}$ and adrenergic nerve dysfunction. ${ }^{10}$ Prolonged vasodilatation of resistance vessels distal to a stenosis may transiently impair the autoregulatory capacity of the vascular bed. ${ }^{11}$

Angioplasty is an effective method for removing the vascular endothelium. ${ }^{12}{ }^{13}$ Balloon injury also splits the vessel wall, disrupting the intima and media, which results in platelet adhesion, the release of constrictor agents and formation of local thrombus. ${ }^{14}$ Within the first minute after final balloon deflation there is a significant reduction in luminal cross sectional area due to the elastic properties of the vessel wall. ${ }^{15} 16$ Coronary artery spasm contributes towards the development of acute closure that occurs in a few patients. ${ }^{17-20}$ Also, there is evidence for spontaneous and progressive vasoconstriction at the dilated and distal sites. ${ }^{2122}$ We have explored the vasomotor responses to papaverine and substance $P$, two drugs that increase coronary blood flow by different mechanisms, in a group of patients undergoing elective PTCA. response after PTCA.

18 December 1992

National Heart and
Lung Institute, London and The Roya Heart and Lung

Diana R Holdrigh

Philip A Poole-Wilso

Kim Fox

Correspondence to:
} 


\section{Patients and methods}

\section{PATIENT SELECTION}

The effects of papaverine and substance $P$ on coronary artery dimensions and coronary blood flow velocity were examined in 15 patients undergoing PTCA who met the following selection criteria: (a) single discrete stenosis in a major epicardial coronary artery suitable for angioplasty and for Doppler probe cannulation, (b) stable anginal symptoms, (c) no features (clinical, electrocardiographic, or echocardiographic) of hypertension or left ventricular hypertrophy, (d) no angiographic evidence of collateral vessels to or from the study vessel, (e) no significant branch vessel arising immediately proximal to the lesion, $(f)$ no angiographic evidence of intracoronary thrombus, and $(g)$ orthogonal views of the stenosis could be taken.

All patients had been referred for elective coronary angioplasty of a discrete coronary stenosis considered to be haemodynamically significant. Patients gave written informed consent before angiography in accordance with guidelines established by the Ethics Committee of the Royal Brompton National Heart and Lung Hospital, which approved the study.

\section{STUDY DESIGN}

Antianginal drugs were not stopped before angioplasty, except for nitrates, which were discontinued at least 24 hours before the study. Instead, attempts were made to standardise treatment according to routine hospital practice. At the time of PTCA 13 patients took a calcium antagonist and four patients took a $\beta$ blocker (of whom two also took a calcium antagonist). Patients arrived at the cardiac catheterisation laboratory in the fasting state. Intravenous heparin gave full anticoagulation. A bipolar temporary pacing wire was positioned in the right ventricle and set on demand at 10 beats $/ \mathrm{min}$ less than the patient's resting heart rate. An 8 French guiding catheter (Medtronic, Minneapolis, USA) was positioned in the left or right coronary ostium and a 0.014 inch guide wire was manipulated across the stenosis. Thirteen patients underwent Doppler flow studies with a 3 French $20 \mathrm{MHz}$ Schneider Doppler flow probe (Schneider, Zurich, Switzerland) that was passed over the guide wire into the coronary artery proximal to the lesion. The Doppler catheter was connected to a Millar velocimeter (Millar Instruments Inc, Texas, USA) for continuous recordings of mean and phasic coronary artery blood flow velocities onto a chart recorder (Lectromed, St Peter, Jersey). The catheter was set at zero and calibrated on a 0 to $40 \mathrm{~cm} . \mathrm{s}^{-1}$ scale and the position and range gating adjusted to optimise the audio velocity signal and the phasic flow velocity waveform. The electrocardiogram, heart rate, and mean and phasic arterial blood pressure were measured continuously.

Pharmacological coronary flow reserve was measured before and after PTCA with papaverine hydrochloride (Macarthy Medical Ltd, UK) diluted in sterile water to a concentration of $4 \mathrm{mg} \cdot \mathrm{ml}^{-1}$ and injected as a bolus of $8 \mathrm{mg}$ through the Doppler catheter selectively into the coronary artery. This dose has been shown to elicit maximum vasodilatation when injected selectively into the coronary artery. ${ }^{23}$ Plasma potassium concentration $T$ and QTc were within normal limits before the study. Endothelium dependent responses were measured before PTCA with substance $P$ (Sigma Chemical Co, UK) that was reconstituted under strict aseptic conditions in $10 \%$ acetic acid to a concentration of $0.1 \mathrm{mg} \cdot \mathrm{ml}^{-1}$ and stored at $-80^{\circ} \mathrm{C}$. Aliquots of the solution were sent for confirmation of assay strength, sterility, and pyrogen testing. Subsequent dilutions were made with $0.9 \%$ sodium chloride solution to provide concentrations of 10 and 15 pmol. $\mathrm{ml}^{-1}$. The final concentrations were made just before the study. All solutions were infused through the Doppler probe with an infusion pump (Becton Dickinson UK Ltd, UK) at a rate of $1 \mathrm{ml} \cdot \mathrm{min}^{-1}$ for two minutes. All patients received the lower dose of substance $P$, which has been shown to elicit maximum vasodilatation. ${ }^{25} 26$ Ten patients also received the higher dose of substance $P$. After the effects of papaverine and substance $\mathbf{P}$ on coronary blood flow had been determined, the Doppler probe was withdrawn and angioplasty performed. About 10 to 15 minutes after successful PTCA the Doppler probe was repositioned in the artery to mimic the position before angioplasty. Once a stable velocity tracing had been established, the effect of PTCA on coronary flow reserve was reassessed with papaverine.

\section{QUANTITATIVE CORONARY ANGIOGRAPHY}

The $x$ ray film gantry was positioned so that orthogonal views could be taken with biplane angiography. The stenotic segment was posi- $\delta$ tioned in the isocentre and the $x$ ray film gantry was not moved after this point. 을 Biplane coronary angiograms were taken at $D$ the start of the protocel and at peak mean velocity response with papaverine and sub- N stance $\mathrm{P}\left(10\right.$ and $\left.15 \mathrm{pmol} \cdot \mathrm{min}^{-1}\right)$. After PTCA repeat control angiograms were taken. O The effect of PTCA on coronary flow reserve $c$ was determined with papaverine and angiograms were taken at peak velocity response. All angiograms were performed with non-ionic contrast media (Omnipaque, Nycomed AS, Norway; iodine content 350 mg. $\mathrm{ml}^{-1}$ ) at an injection rate of $5-8 \mathrm{ml} . \mathrm{s}^{-1}$.

Angiographic data were acquired digitally $\mathbb{D}$ in a $512 \times 512$ matrix with 10 bit depth on a real time digital image acquisition and analysis system (Digitron III VACI, Siemens AG, 응 Germany) at 12.5 frames. $\mathrm{s}^{-1}$ (dose rate $25 \mu \mathrm{m}$ Roentgen.frame ${ }^{-1}$ with gap filling, in a $17 \mathrm{~cm}$ nominal input field and $0.8 \mathrm{~mm}^{2}$ focal spot. A low lag, 1249 line progressive scan video camera (Videomed C) was directly coupled to the image intensifier. The analogue output of the video camera was digitised in real time with a linear lookup 
table relating radiographic density to Gray level, with parallel transfer via a solid state buffer, and stored on $4 \times 740$ Winchester hard disks. To correct for geometric magnification, calibration was determined from the diameter of the guiding catheter, which was measured with hand held micrometer calipers after each study. The algorithm for automatic edge detection of digital data incorporated the weighted sum of the first and second derivatives to detect the vessel edge. The methods of acquisition and analysis were validated with contrast filled perspex phantoms of cylindrical wells ranging from 1 to $4 \mathrm{~mm}$ in diameter. The mean difference between the measured and the real diameter (accuracy) was $-220 \mu \mathrm{m}$ and the pooled SD of the differences (precision) was $80 \mu \mathrm{m}$. Short and long-term within observer variability were determined by repeated analysis of six digitally acquired angiograms. A total of 36 coronary arterial segments (six per angiogram) were reanalysed 24-72 hours and six months after the original analysis. The largest mean diameter difference for any one angiogram was $\pm 30 \mu \mathrm{m}$ (short-term) and $\pm 40 \mu \mathrm{m}$ (long-term). There were no significant differences between measurements made at these times compared with the original analysis.

\section{AREA, VELOCITY, AND FLOW MEASUREMENTS}

Measurements of vessel diameter were made at three points (proximal and distal to the lesion and at the stenotic site) along the artery in both planes. The proximal and distal sites corresponded with angiographically normal arterial segments. The proximal site was located about $2-4 \mathrm{~mm}$ distal to the tip of the Doppler flow probe. The distal site corresponded with an arterial segment distal to the stenotic site that could be readily identified by vessel side branches in both angiographic views.

Area measurements were calculated from the mean luminal diameter measured in orthogonal views, with the equation:

Cross sectional area $=\pi \times \mathrm{r}_{1} \times \mathrm{r}_{2}$

where $r_{1}$ and $r_{2}$ are the radii calculated from the diameters measured in the two views.

Measurements were made before infusion (control area) and at peak velocity change (intervention area). Percentage area change was calculated as (intervention area-control area)/control area $\times 100 \%$. The velocity ratio was calculated as the ratio of peak mean velocity $\left(\mathrm{cm} . \mathrm{s}^{-1}\right)$ during infusion to baseline mean velocity $\left(\mathrm{cm} . \mathrm{s}^{-1}\right)$ immediately before infusion. Estimates of coronary flow were derived from the product of cross sectional area and velocity at baseline and at peak response, and were expressed in $\mathrm{ml} . \mathrm{min}^{-1}$. This allowed calculation of a flow ratio as the quotient of peak flow/baseline flow.

\section{STATISTICAL ANALYSIS}

All data are expressed as mean (SEM). Nonparametric statistical analysis was performed on the data, by the Wilcoxon matched pairs signed rank sum test for paired data and the Mann-Whitney test for unpaired data. Relations between different variables were assessed by Pearson's correlation coefficient.

\section{Results}

\section{PATIENT CHARACTERISTICS}

Fifteen consecutive patients, including two women, undergoing elective PTCA of a discrete stenosis, who fulfilled the selection criteria and gave written informed consent were studied (table 1). Mean age was 57.0 (1.4) years. No patient had clinical, electrocardiographic, or echocardiographic evidence of hypertension or left ventricular hypertrophy. Left ventricular mass, measured in echogenic subjects $(n=12)$ according to the Penn convention, ${ }^{27}$ was 90 (8) $\mathrm{gm}^{-2}$. No patient had diabetes mellitus. Ten patients had a family history of ischaemic heart disease. Eight patients were ex-cigarette smokers and one patient was a current smoker. Four patients had a history of myocardial infarction and pathological $Q$ waves on the resting electrocardiogram (three inferior, one anterior). No patient had symptoms suggestive of left ventricular dysfunction and no patient took diuretics or angiotensin converting enzyme inhibitors. Left ventricular dimensions measured echocardiographically were within normal limits and the cardiothoracic ratio estimated from the posteroanterior chest $x$ ray film was $<0.5$ in all cases. The mean left ventricular end diastolic pressure was $13.6(1 \cdot 3)$

Table 1 Patient characteristics

\begin{tabular}{|c|c|c|c|c|c|c|c|c|c|}
\hline Patient & $\begin{array}{l}\text { Age } \\
(y r)\end{array}$ & Sex & $\begin{array}{l}\text { Dur } A P \\
\text { (months) }\end{array}$ & $M I$ & Smoker & $\begin{array}{l}B P \text { syst } \\
(m m \mathrm{Hg})\end{array}$ & $\begin{array}{l}B P \text { diast } \\
(m m \mathrm{Hg})\end{array}$ & $\begin{array}{l}\text { Cholesterol } \\
\left(\mathrm{mmol}^{-1}\right)\end{array}$ & $\begin{array}{l}\text { Glucose } \\
\left(\text { mmol. }^{-1}\right)\end{array}$ \\
\hline $\begin{array}{l}1 \\
2 \\
3 \\
4 \\
5 \\
6 \\
7 \\
8 \\
9 \\
10 \\
11 \\
12 \\
13 \\
14 \\
15\end{array}$ & $\begin{array}{l}51 \cdot 2 \\
59 \cdot 8 \\
59 \cdot 9 \\
55 \cdot 8 \\
60 \cdot 9 \\
64 \cdot 8 \\
64 \cdot 3 \\
53 \cdot 3 \\
52 \cdot 8 \\
50 \cdot 6 \\
49 \cdot 8 \\
65 \cdot 3 \\
56 \cdot 6 \\
53.9 \\
56 \cdot 3\end{array}$ & $\begin{array}{l}M \\
M \\
M \\
M \\
M \\
M \\
M \\
M \\
M \\
M \\
M \\
M \\
F \\
M \\
F\end{array}$ & $\begin{array}{c}24 \\
12 \\
12 \\
0^{\star} \\
12 \\
36 \\
24 \\
20 \\
14 \\
9 \\
18 \\
60 \\
14 \\
7 \\
22\end{array}$ & $\begin{array}{l}0 \\
\text { Inf } \\
\text { Inf } \\
\text { Ant } \\
0 \\
0 \\
0 \\
0 \\
\text { Inf } \\
0 \\
0 \\
0 \\
0 \\
0 \\
0\end{array}$ & $\begin{array}{l}20 / \text { day } \\
\mathrm{Ex} \\
\mathrm{Ex} \\
0 \\
0 \\
\mathbf{E x} \\
0 \\
\mathrm{Ex} \\
\mathrm{Ex} \\
\mathrm{Ex} \\
0 \\
0 \\
0 \\
\mathbf{E x} \\
\mathbf{E x}\end{array}$ & $\begin{array}{l}130 \\
120 \\
130 \\
110 \\
130 \\
110 \\
165 \\
130 \\
110 \\
125 \\
115 \\
140 \\
140 \\
165 \\
140\end{array}$ & $\begin{array}{l}80 \\
70 \\
70 \\
70 \\
70 \\
70 \\
80 \\
70 \\
70 \\
75 \\
75 \\
85 \\
80 \\
85 \\
85\end{array}$ & $\begin{array}{l}6 \cdot 5 \\
7 \cdot 8 \\
5 \cdot 6 \\
6 \cdot 3 \\
5 \cdot 5 \\
4 \cdot 9 \\
7 \cdot 0 \\
5 \cdot 6 \\
7 \cdot 1 \\
5 \cdot 9 \\
\\
5 \cdot 9 \\
5 \cdot 2\end{array}$ & $\begin{array}{l}4 \cdot 2 \\
5 \cdot 5 \\
4 \cdot 7 \\
5 \cdot 2 \\
5 \cdot 1 \\
6 \cdot 2 \\
6 \cdot 8 \\
5 \cdot 2 \\
4 \cdot 2 \\
6 \cdot 7 \\
\\
5 \cdot 1 \\
5 \cdot 6\end{array}$ \\
\hline
\end{tabular}

Dur AP duration of angina pectoris; MI previous myocardial infarction; BP syst and diast, systolic and diastolic blood pressure; *angioplasty was performed for exercise related ventricular tachycardia thought to be ischaemic in origin. 
Table 2 Minimum luminal area and coronary blood flow before and after angioplasty

\begin{tabular}{|c|c|c|c|c|c|c|c|c|}
\hline \multirow[b]{2}{*}{ Patient } & \multicolumn{4}{|c|}{ Before angioplasty } & \multicolumn{4}{|c|}{ After angioplasty } \\
\hline & $\begin{array}{l}M L A \\
\left(m m^{2}\right)\end{array}$ & $\begin{array}{l}\text { Flow (B) } \\
(\text { ml.min }\end{array}$ & 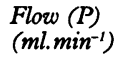 & $C F R$ & $\begin{array}{l}M L A \\
\left(m m^{2}\right.\end{array}$ & $\begin{array}{l}\text { Flow (B) } \\
\left(\text { ml.min }^{-1}\right)\end{array}$ & $\begin{array}{l}\text { Flow (P) } \\
\left(\text { ml.min }^{-1}\right)\end{array}$ & $C F R$ \\
\hline $\begin{array}{l}1 \\
2 \\
3 \\
4 \\
5 \\
6 \\
7 \\
8 \\
9 \\
10 \\
11 \\
12 \\
13 \\
\text { Mean }\end{array}$ & $\begin{array}{l}1 \cdot 8 \\
- \\
- \\
2 \cdot 1 \\
1 \cdot 9 \\
2 \cdot 1 \\
3 \cdot 8 \\
1 \cdot 9 \\
2 \cdot 4 \\
3 \cdot 9 \\
1 \cdot 1 \\
- \\
- \\
2 \cdot 3(0 \cdot 3)\end{array}$ & $\begin{array}{l}22 \\
9 \\
13 \\
- \\
39 \\
16 \\
53 \\
48 \\
38 \\
33 \\
25 \\
53 \\
84 \\
36(6)\end{array}$ & $\begin{array}{l}23 \\
18 \\
30 \\
- \\
90 \\
54 \\
100 \\
46 \\
117 \\
167 \\
79 \\
52 \\
85 \\
72(13)\end{array}$ & $\begin{array}{l}1 \cdot 1 \\
2.0 \\
2 \cdot 4 \\
- \\
2.3 \\
3.3 \\
1.9 \\
0.9 \\
3.1 \\
5.0 \\
3 \cdot 1 \\
1.0 \\
1.0 \\
2.3(0 \cdot 4)\end{array}$ & $\begin{array}{l}3 \cdot 8 \\
1 \cdot 7 \\
3 \cdot 5 \\
2 \cdot 7 \\
3 \cdot 0 \\
4 \cdot 1 \\
6 \cdot 3 \\
4 \cdot 3 \\
5 \cdot 4 \\
4 \cdot 7 \\
1 \cdot 8 \\
5 \cdot 2 \\
-3 \cdot 9(0 \cdot 4)^{\star}\end{array}$ & $\begin{array}{l}76 \\
56 \\
25 \\
127 \\
56 \\
18 \\
43 \\
44 \\
36 \\
36 \\
25 \\
47 \\
178 \\
59(13)\end{array}$ & $\begin{array}{l}120 \\
133 \\
53 \\
213 \\
322 \\
70 \\
72 \\
85 \\
143 \\
161 \\
135 \\
120 \\
256 \\
145(22)^{\star}\end{array}$ & $\begin{array}{l}1 \cdot 6 \\
2 \cdot 4 \\
2 \cdot 1 \\
1 \cdot 7 \\
5 \cdot 8 \\
3 \cdot 9 \\
1 \cdot 7 \\
1 \cdot 9 \\
4 \cdot 0 \\
4 \cdot 5 \\
5 \cdot 4 \\
2 \cdot 5 \\
1 \cdot 4 \\
3 \cdot 0(0 \cdot 4)^{\star}\end{array}$ \\
\hline
\end{tabular}

Patients 14 and 15 did not have Doppler flow measurements; $(-)$ angiographic measurements could not be made for technical reasons (poor opacification or vessel overlap). CFR coronary flow reserve: Flow $(B)$ and $(P)$, baseline and peak flow: MLA, reasons (poor opacification or vessel overlap). CFR, coronary flow reserve: Flow $(B)$ and $(\mathrm{P})$, baseline and
minimum luminal area at the stenotic site. ${ }^{\star} \mathrm{p}<0.05 \mathrm{v}$ before PTCA value: $(+) \mathrm{p}<0.01 \mathrm{v}$ before PTCA value.

mm Hg. Six patients took nitrates, which were stopped at least 24 hours before angioplasty. Other antianginal treatment was continued in accordance with our hospital practice, but an attempt was made to standardise the antianginal regimen.

Seven patients had single vessel coronary artery disease and the rest had two vessel disease. The lesion for angioplasty was in the left anterior descending artery in six patients, in the right coronary artery in six patients, and in the circumflex coronary artery in the rest. The angioplasty balloon sizes ranged from 2.5 to $3.5 \mathrm{~mm}$. The mean number of balloon inflations during the study was 1.8 (range one to three, and mean total inflation time was 123 (range 30-210) s. Mean maximum inflation pressure was 7.5 (range 4-12) Bar (1 Bar $=100 \mathrm{kPa}$ ).

After PTCA resting coronary artery area increased significantly at distal sites $(4.7(0.5)$ $\mathrm{mm}^{2}$ before $v 5.5(0.4) \mathrm{mm}^{2}$ after PTCA, $p<0.05)$. There was no change in area at proximal sites $\left(8.5(0.7) \mathrm{mm}^{2}\right.$ before $v 8.6$ $(0.7) \mathrm{mm}^{2}$ after angioplasty, NS). Percentage area stenosis was significantly reduced by angioplasty from $75 \%(3 \%)$ to $53 \%(4 \%)$ (p $<0.05)$. Minimum luminal area at the site of stenosis increased significantly from $2 \cdot 3(0 \cdot 3)$ $\mathrm{mm}^{2}$ to $3.9(0.4) \mathrm{mm}^{2}(\mathrm{p}<0.01)$ (table 2$)$.

\section{EFFECT OF PAPAVERINE ON LUMINAL}

DIMENSIONS

The effect of papaverine on coronary artery area varied according to the site and whether or not PTCA had been performed. There was

Figure 1 Changes in epicardial coronary artery area with papaverine before and after angioplasty at proximal, distal, and stenotic sites. $\star_{p}<0.05$ v baseline.

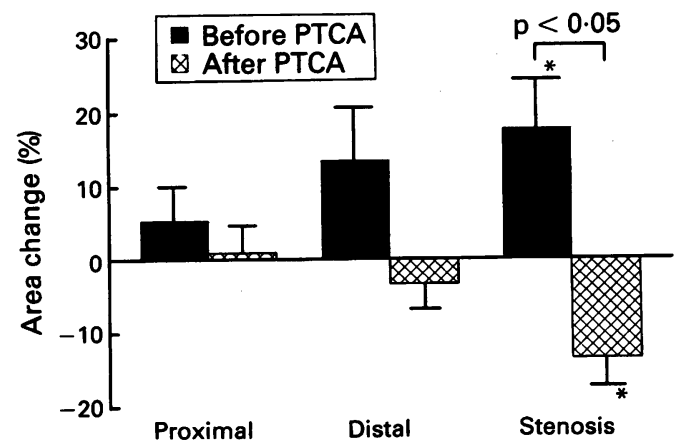

no significant change in epicardial coronary artery area before PTCA $(5 \cdot 4 \%(4.6 \%)$ area increase at the proximal site; $13.5 \%(8 \cdot 1 \%)$ area increase at the distal site, both NS $v$ baseline; (fig 1). Papaverine caused significant dilatation at the stenotic site $(17 \cdot 7 \%(6 \cdot 9 \%)$ area increase, $\mathrm{p}<0.05 v$ baseline) before PTCA that was not seen after PTCA (fig 2). Significant vasoconstriction was produced with papaverine at the stenotic site after PTCA $(-13.6 \% \quad(4 \cdot 3 \%)$ area change, $\mathrm{p}<0.05 v$ baseline). After PTCA papaverine did not significantly alter luminal dimensions at the proximal site $(0.9 \%(3.3 \%)$ area change, NS $v$ baseline) or distal site $(-3.5 \%$ $(4 \cdot 0 \%)$ area change, NS $v$ baseline). There was a negative correlation between the percentage area change with papaverine before and after PTCA at the stenotic site $(r=-0.68, \mathrm{p}<0.05)$. Those lesions that dilated most with papaverine before PTCA tended to show greater constrictor responses with papaverine after PTCA.

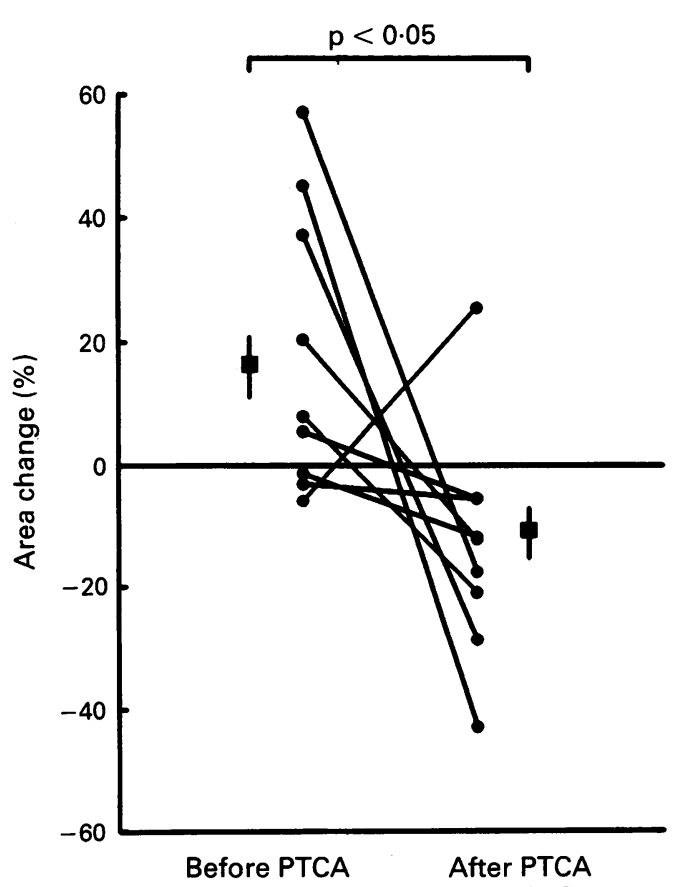

Figure 2. The effect of angioplasty on individual responses to papaverine at the stenotic site. Means (SEM) are indicated. 
CORONARY FLOW RESERVE

Coronary flow reserve measured with papaverine increased from $2.3(0.4)$ to 3.0 $(0.4)$ ( $p<0.05$ before $v$ after PTCA; fig 3). There was no correlation between coronary flow reserve and minimum luminal area of the dilated segment before or after PTCA. Baseline flow did not rise after the procedure

Figure 3 Individual coronary flow reserve with papaverine measured before and after angioplasty. Means (SEM) are indicated.

Figure 4 Individual baseline and peak blood flow with papaverine before and after angioplasty. Means (SEM) are indicated.

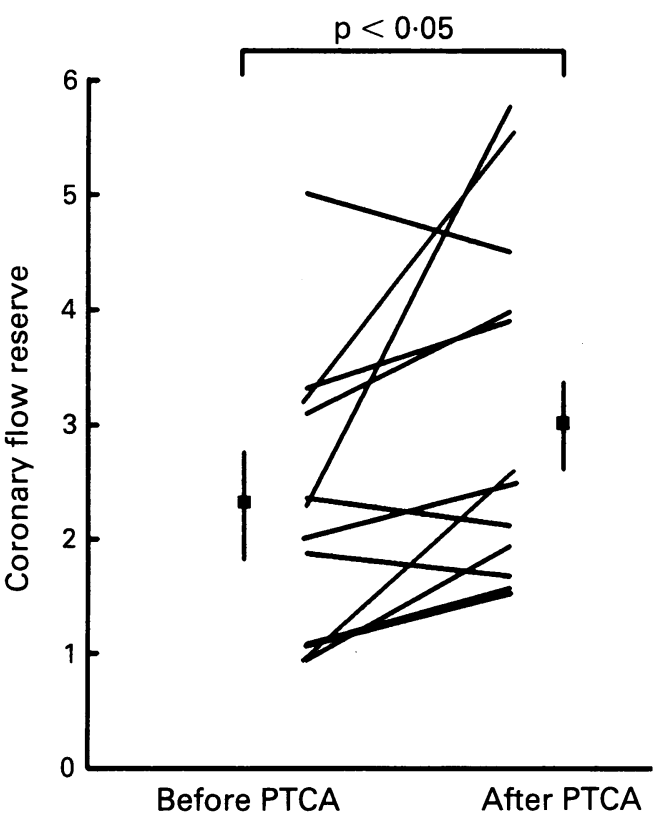

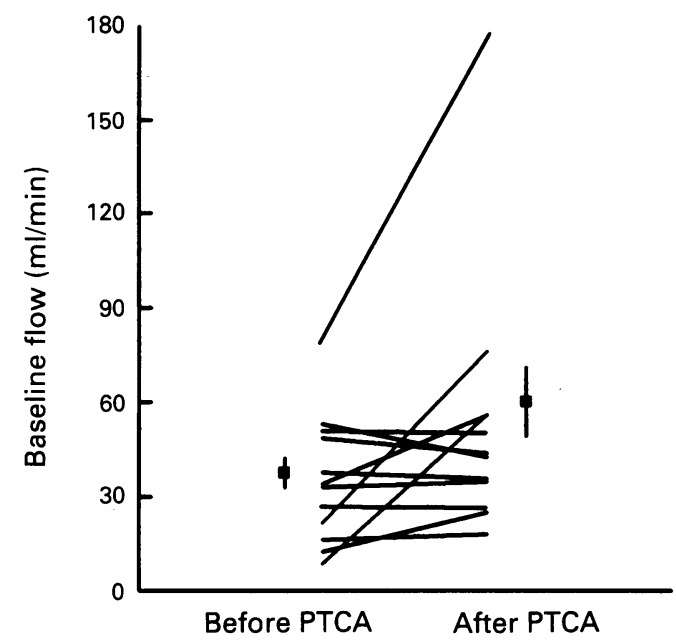

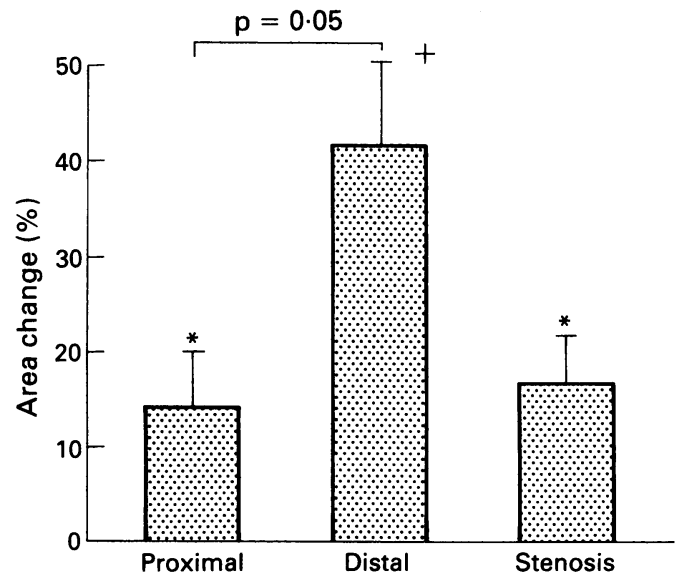

Figure 5 Percentage (SEM) area change with substance $P$ at proximal, distal, and stenotic sites. ${ }^{\star} p<0.05 v$ baseline; $(+) p<0.005 v$ baseline.

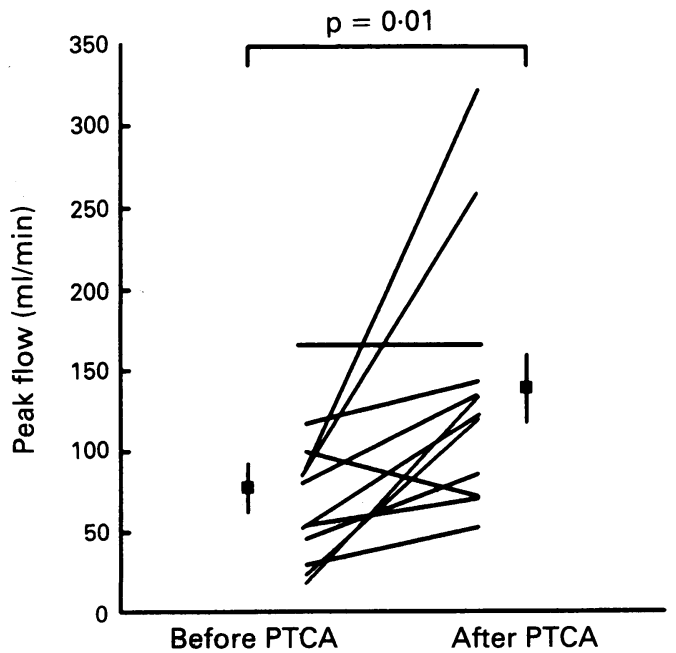
area $(r=0.63, \mathrm{p}=0.07)$ before PTCA.

THE EFFECTS OF SUBSTANCE $P$

The effects of substance $P$ on coronary blood flow velocity and coronary artery area were measured before PTCA. Coronary blood flow increased with substance $P\left(10\right.$ pmol. $\mathrm{min}^{-1}$ (flow ratio $1.8(0.4), \mathrm{n}=10, \mathrm{p}=0.01 v$ baseline) and 15 pmol. $\mathrm{min}^{-1}$ (flow ratio $2 \cdot 0(0 \cdot 4)$, $\mathrm{n}=8, \mathrm{p}=0.01 v$ baseline)). Significant coronary artery dilatation occurred at all three sites but there was considerable variation between patients (fig 5, table 3). Stenotic and proximal sites dilated significantly with substance $P(16.8 \%(5 \cdot 7 \%)$ area increase at the stenotic site $v 14.3 \%(5.4 \%)$ area increase at the proximal site). Distal sites showed the greatest dilator response $(41 \cdot 7 \%(9 \cdot 3 \%)$ area increase, $\mathrm{p}<0.005 v$ baseline).

\begin{tabular}{|c|c|c|c|}
\hline Patient & Proximal & Distal & Stenotic \\
\hline 1 & $-4 \cdot 2$ & $89 \cdot 2$ & $42 \cdot 9$ \\
\hline 2 & - & - & - \\
\hline 3 & $19 \cdot 0$ & $66 \cdot 3$ & - \\
\hline 4 & $-16 \cdot 2$ & $34 \cdot 2$ & $0 \cdot 0$ \\
\hline 5 & - & - & - \\
\hline 6 & $39 \cdot 0$ & $14 \cdot 3$ & $17 \cdot 8$ \\
\hline 7 & 11.0 & $69 \cdot 7$ & $15 \cdot 5$ \\
\hline 8 & $49 \cdot 8$ & $-2 \cdot 3$ & $20 \cdot 4$ \\
\hline 9 & 14.4 & $-14 \cdot 2$ & $40 \cdot 2$ \\
\hline 10 & $44 \cdot 7$ & 94.9 & $-4 \cdot 1$ \\
\hline 11 & $8 \cdot 7$ & 33.9 & -1.3 \\
\hline 12 & $6 \cdot 2$ & 45.5 & - \\
\hline
\end{tabular}

(36(6) ml.min ${ }^{-1}$ before PTCA v 59(13) ml.min ${ }^{-1}$ after PTCA, $p=0.2$; fig 4) but there was a significant increase in peak blood flow with papaverine $\left(72(13) \mathrm{ml} \cdot \mathrm{min}^{-1}\right.$ before PTCA $v$ 145(22) $\mathrm{ml} \cdot \mathrm{min}^{-1}$ after PTCA, $p=0.01$ ). There was a significant correlation between peak flow with papaverine and minimum luminal area before PTCA $(r=0.75, \mathrm{p}<0.05)$ that was not seen after angioplasty. A weak correlation was found between basal flow and minimum luminal 


\section{Discussion}

The beneficial effect of PTCA on myocardial perfusion cannot necessarily be predicted from the angiogram immediately after PTCA. Despite an improvement in anatomical measures of stenosis severity, coronary flow reserve with papaverine remained $<3.5$ in eight of 13 patients. Furthermore, the vasodilator response to papaverine at the stenotic site was converted to a vasoconstrictor action after PTCA. The vasodilatation to substance $P$ before PTCA in most patients suggests that endothelium dependent dilatation can be elicited in atherosclerotic coronary arteries, even at stenotic sites. Angioplasty causes endothelial denudation, resulting in the loss of endothelium dependent vasodilatation and the release of powerful vasoconstrictors, which may contribute towards the paradoxical response to papaverine after PTCA. The mechanisms underlying vasoconstriction with papaverine may also give rise to impaired coronary perfusion during physical manoeuvres, for example exercise, which increase myocardial oxygen demand.

Abnormal vasomotor changes after PTCA $^{2829}$ may contribute to the impairment of coronary flow reserve, which gradually improves or even becomes normal in the absence of restenosis, possibly due to remodelling of the lesion. ${ }^{30-33}$ In our patients coronary flow reserve improved with PTCA but did not become normal. Coronary flow reserve did not correlate with minimum luminal area or percentage area stenosis before or after PTCA; nor was the impairment of coronary flow reserve explained by an increase in basal blood flow, a phenomenon that has been found in many ${ }^{31134-36}$ but not all2,37,38 studies.

A bolus of intracoronary papaverine, a phosphodiesterase inhibitor ${ }^{39}$ is a well established method for measuring pharmacological coronary flow reserve. ${ }^{23}$ In normal coronary arteries papaverine increases epicardial coronary artery area by about $14 \% .40$ Stenotic coronary artery area increases with papaverine by $18 \%(7 \%),{ }^{41}$ which is similar to our data. The constrictor response to papaverine at the stenotic site after PTCA has not been previously reported. Translesional pressure gradients have been measured before and after PTCA during papaverine induced hyperaemia. Despite satisfactory angiographic results after PTCA a translesional pressure gradient of $\geqslant 10 \mathrm{~mm} \mathrm{Hg}$ was induced by intracoronary papaverine in $50 \%$ of patients. ${ }^{42}$ This finding may have resulted from vasoconstriction occurring at the stenotic site during papaverine induced hyperaemia.

Several mechanisms may contribute to the paradoxical response seen with papaverine after PTCA, including the release of vasoconstrictor agents from platelets and the vessel wall, ${ }^{6}$ altered arachidonate metabolism, ${ }^{9}$ and adrenergic nerve dysfunction..$^{10}$ Prolonged vasodilatation of resistance vessels distal to a stenosis may transiently impair the autoregulatory capacity of the vascular bed. ${ }^{11}$ Flow mediated vasoconstriction may occur as a result of the rapid release of endothelin in response to flow increases. ${ }^{43}$ Loss of endothelium dependent vasodilatation may also be important. ${ }^{5}$ Although the endothelium shows widespread abnormalities in atherosclerotic vessels ${ }^{44}$ our data indicate that endothelium dependent responses to substance $P$ can be shown. The endothelium releases endothelium derived relaxing factor, ${ }^{45}$ which causes vasodilatation by a direct action on underlying vascular smooth muscle. Endothelium dependent dilatation is impaired in patients with atheromatous coronary artery disease ${ }^{46}$ and in patients with angiographically normal coronary arteries who have risk factors for the development of atheromatous change. ${ }^{47}$ The normal dilator response to intracoronary acetylcholine and serotonin is converted into a constrictor response in diseased coronary arteries. ${ }^{46} 48-50$ Substance $P$ is a neuropeptide that causes endothelium dependent dilatation in normal coronary arteries. ${ }^{25}{ }^{51}$ Crossman et al have shown by autoradiography that binding sites for substance $P$ are present on the luminal cell surface of atherosclerotic coronary arteries. ${ }^{26}$ Whereas angiographically diseased coronary arteries uniformly constrict to acetylcholine ${ }^{46}$ we found a dilator response to substance $P$ at the stenotic site in most patients. Distal sites showed the largest and most consistent responses, similar to data from angiographically normal coronary arteries. ${ }^{25}$ Our results indicate that endothelium dependent dilator responses are not invariably lost in coronary artery disease. Endothelial denudation as a result of balloon angioplasty would abolish these responses, however, and may contribute to vasoconstriction during hyperaemic flow after PTCA. Furthermore, endothelium dependent flow mediated dilatation ${ }^{52}$ would be lost, thereby enabling the myogenic response to operate unopposed. ${ }^{8}$

We could not assess endothelium dependent responses to substance P after PTCA to test this hypothesis because progressive vasoconstriction occurs after PTCA. ${ }^{21} 22$ As substance $P$ was infused over a two minute period in our protocol, the end result would represent the sum of two opposing actionsthat is, dilatation with substance $\mathbf{P}$ and progressive vasoconstriction as a result of PTCA. Thus, it would not be possible to dissect out the contributions from these two opposing mechanisms. We can only postulate that dilator responses to substance $\mathrm{P}$ would be lost after PTCA. Based on data from animal and in vitro studies we think that this is likely to occur. Although we cannot be certain that balloon inflation caused endothelial denudation, there is considerable evidence from studies in animals that this occurs. ${ }^{12}{ }^{13}$ Indeed, in in vitro studies the endothelium is intentionally removed by gentle rubbing of the intimal surface.

Finally, we considered the possibility that the negative correlation between the vasodilator response to papaverine at the stenotic site before PTCA and the vasoconstrictor 
response after PTCA was due to some intrinsic anatomical feature of the stenosis that regulated the extent to which a stenotic segment could undergo active vasomotion. For example, eccentric lesions are capable of greater vasomotor changes than concentric lesions. An experienced cardiac radiologist, blinded to the results, graded the lesion eccentricity of the 15 stenoses $(0=$ concentric, $1=$ mildly eccentric, $2=$ moderately eccentric, $3=$ severely eccentric). The results were compared with the degree of vasomotion as a result of papaverine, but no correlation was evident. Similarly, Fischell and Bausbeck have shown that the degree of progressive vasoconstriction in the dilated segment after PTCA does not differ in eccentric versus concentric lesions. ${ }^{53}$

\section{LIMITATIONS}

We examined the vasomotor responses in different coronary arteries depending on the site of the stenosis. There was no evidence that responses differed in different coronary arteries, and we are unaware of any studies that conflict with our findings. In three patients the artery studied was an infarct related atery. Conceivably, vasomotor responses in an infarct related artery may be different, but there was no suggestion that this was the case. We cannot be certain that the vasomotor responses elicited in our patients were unaffected by concomitant antianginal treatment. Other than nitrates, antianginal medication was not stopped. Instead, we attempted to standardise treatment according to our hospital practice so that most patients were maintained on a calcium antagonist for the PTCA. Release of endothelium dependent relaxing factor is a calcium dependent process, but it is not inhibited by calcium antagonists. ${ }^{54}$

In conclusion, we have shown endothelium dependent relaxation in response to substance $\mathrm{P}$ in patients with coronary artery disease, even at sites of overt atheroma. The act of balloon angioplasty converted a dilator response to papaverine into a constrictor response at the dilated site. This paradoxical response probably results from several distinct mechanisms, one of which may be an unopposed flow mediated myogenic response after balloon mediated endothelial denudation. Abnormal vasomotor responses as a result of PTCA may explain why some patients remain symptomatic in the absence of angiographic restenosis.

We thank Dr M Raphael for his assistance in the assessment of lesion morphology. DRH holds a Bristol-Myers Squibb Cardiovascular Fellowship.

1 O'Neill WW, Walton JA, Bates ER, et al. Criteria for successful coronary angioplasty as assessed by alterations in coronary vasodilatory reserve. $\mathcal{f}$ Am Coll Cardiol 1984 3:1382-90

2 Hodgson J McB, Riley RS, Most AS, Williams DO Assessment of coronary flow reserve using digital angiography before and after successful percutaneous transluminal coronary angioplasty. Am $\mathcal{f}$ Cardiol 1987 60:61-5.

3 Nanto S, Kodama K, Hori M, et al. Temporal increase in resting coronary blood flow causes an impairment of coronary flow reserve after coronary angioplasty. $A m$ Heart f 1992;123:28-36.

4 El-Tamimi H, Davies GJ, Sritara P, Hackett D, Crea F, Maseri A. Inappropriate constriction of small coronary vessels as a possible cause of a positive exercise test early vessels as a possible cause of a positive exercise test early after success

5 Fischell TA, Ginsburg R. Loss of endothelium-dependent relaxation following balloon angioplasty. $\mathcal{F}$ Applied Cardiology 1987;2:489-504.

6 Bing ER, Aueron FM, Legrand V, et al. Effect of intact endothelium against platelet-induced coronary artery spasm in isolated rabbit hearts. Am $\mathcal{F}$ Cardiol 1985; 55:1596-600.

7 Wilson RF, Laxon DD, Lesser JR, White CW. Intense microvascular constriction after angioplasty of acute thrombotic coronary arterial lesions. Lancet 1989;i: thrombo

8 Bevan JA. Vascular myogenic or stretch-dependent tone. f Cardiovasc Pharm 1985;7(suppl 3):S129-36.

9 Cragg A, Einzig S, Castenada-Zuniga W, Amplatz K, White JG, Rao GH. Vessel wall arachidonate metabolism after angioplasty: possible mediators of post-angioplasty vasospasm. Am $\mathcal{f}$ Cardiol 1983;51:1441-5.

10 Cohen RA, Zitnay KM, Weisbrod RM. Accumulation of 5-hydroxytryptamine leads to dysfunction of adrenergic nerves in canine coronary artery following intimal damage in vivo. Circ Res 1987;61:829-33.

11 Kern MJ, Deligonul U, Vandormael M, et al. Impaired coronary vasodilator reserve in the immediate postcoronary angioplasty period; analysis of coronary artery flow nary angioplasty period; analysis of coronary artery flow
velocity indexes and regional cardiac venous efflux. $\mathcal{F}$ velocity indexes and regional cardi

12 Bates ER, McGillem MJ, Beals TF, et al. Effect of angioplasty induced endothelial denudation compared with medial injury on regional coronary blood flow. Circulation 1987;76:710-6.

13 Shimokawa H, Aarhus LL, Vanhoutte PM. Porcine coronary arteries with regenerated endothelium have reduced endothelium-dependent responsiveness to aggregating platelets and serotonin. Circ Res 1987; 61:256-70

14 Steele PM, Chesebro JH, Stanson AW, et al. Balloon angioplasty. Natural history of the pathophysiological response to injury in a pig model. Circ Res 1985; 57:105-12.

15 Rensing BJ, Hermans WRM, Beatt KJ, et al. Quantitative angiographic assessment of elastic recoil after percutaneous transluminal coronary angioplasty. $\mathrm{Am} \mathcal{F}$ Cardiol 1990;66:1039-44.

16 Rensing BJ, Hermans WR, Strauss BH, Serruys PW. Regional differences in elastic recoil after percutaneous transluminal coronary angioplasty: a quantitative angiographic study. $\mathcal{F}$ Am Coll Cardiol 1991;17:34B-8.

17 Cowley MJ, Dorros G, Kelsey SF, Van Reden M, Detre KM. Acute coronary events associated with percutaneous transluminal coronary angioplasty. $A m \mathcal{f} \mathrm{Cardiol}$ 1984;53(suppl C): $12 c-6$.

18 Hollman J, Austen GE, Gruentzig AR, Douglas JS, King SB. Coronary artery spasm at the site of angioplasty in the first two months after successful percutaneous transluminal coronary angioplasty. $\mathcal{F} \mathrm{Am}$ Coll Cardiol 1983; 2:1039-45.

19 Quyyumi AA, Raphael M, Perrins EJ, Shapiro L, Rickards $\mathrm{AF}$, Fox KM. Incidence of spasm at the site of previous successful transluminal coronary angioplasty: effect of ergometrine maleate in consecutive patients. $\mathrm{Br}$ Heart $\mathrm{f}$ 1986;56:27-32.

20 Leisch F, Harringer W, Kerschner K, Hofmann R, Feirer G, Schutzenberger W. Importance of coronary spasm for recurrences following percutaneous transluminal for recurrences following percutaneous transluminal coronary

21 Sanders $M$. Angiographic changes thirty minutes following percutaneous transluminal coronary angioplasty. Angiology 1985;36:419-23.

22 Fischell TA, Derby G, Tse TM, Stadius ML. Coronary artery vasoconstriction routinely occurs after percutaneous transluminal coronary angioplasty. Circulation 1988;78:1323-34.

23 Wilson RF, White CW. Intracoronary papaverine: an ideal coronary vasodilator for studies of the coronary circulation in conscious humans. Circulation 1986;73:444-51.

24 Drexler H, Zeiher AM, Wollschlager H, Meinertz T, Just $\mathrm{H}$, Bonzel T. Flow-dependent coronary artery dilatation in humans. Circulation 1989;80:466-74.

25 Crossman DC, Larkin SW, Fuller RW, Davies GJ, Maseri A. Substance $P$ dilates epicardial coronary arteries and A. Substance $P$ dilates epicardial coronary arteries and increases coronary

26 Crossman DC, Larkin SW, Dashwood MR, et al. Responses of atherosclerotic human coronary arteries in vivo to the endothelium-dependent vasodilator substance P. Circulation 1991;84:2001-10.

27 Devereux RB, Reichek N. Echocardiographic determination of left ventricular mass in man: anatomic validation of the method. Circulation 1977;55:613-8

28 El-Tamimi H, Davies GJ, Hackett D, et al. Abnormal vasomotor changes early after coronary angioplasty. Circulation 1991;84:1198-202. 
29 Suter TM, Bucchi M, Hess OM, Haemmerli-Saner C, Gaglione A, Krayenbuehl HP. Normalisation of coronary vasomotion after percutaneous transluminal coronary angioplasty? Circulation 1992;85:86-92

30 Laarman GJ, Serruys PW, Suryapranata H, et al. Inability of coronary blood flow reserve measurements to assess the efficacy of coronary angioplasty in the first 24 hours in unselected patients. Am Heart $¥$ 1991;122:631-9.

31 Bates ER, Aueron FM, Legrand V, et al. Comparative long-term effects of coronary artery bypass graft surgery and percutaneous transluminal coronary angioplasty on regional

32 Wilson RF, Johnson MR, Marcus ML, et al. The effect of coronary angioplasty on coronary flow reserve. Circulation 1988;77:873-85.

33 Zijlstra A, Reiber JHC, Juilliere Y, Serruys PW. Normalisation of coronary flow reserve by percutaneous transluminal coronary angioplasty. $A m \mathcal{F}$ Cardiol 1988; 61:55-60.

34 Hartzler GO, Smith HC, Vliestra RE, et al. Coronary blood-flow responses during successful percutaneous transluminal coronary angioplasty. Mayo Clin Proc 1980;55:45-9.

35 Rothman MT, Baim DS, Simpson JB, et al. Coronary hemodynamics during percutaneous transluminal coronary angioplasty. $A m \mathcal{F}$ Cardiol 1982;49:1615-22.

36 Canty JM, Klocke JF. Reduced regional myocardial perfusion in the presence of pharmacogical vasodilator reserve. Circulation 1984;71:370-7.

37 Feldman RL, Conti R, Pepine CJ. Regional coronary venous flow responses to transient coronary artery
occlusion in human beings. $\Im \mathrm{Am}$ Coll Cardiol 1983;2: 1-11.

38 Serruys $P W, W i j n s$, van den Brand $M$, et al. Left ventricular performance, regional blood flow, wall motion, and lactate metabolism during transluminal angioplasty. Circulation 1984;70:25-36.

39 Triner L, Vulliemoz Y, Schwartz I, Nahas G. Cyclic phosTriner L, Vulliemoz Y, Schwartz I, Nahas

40 Carlson EB, Gilliam FR, Bashore TM. Changes in epicardial coronary arterial diameter following intracoronary papaverine in man. Cathet Cardiovasc Diagn 1988; 14:150-3.

41 Zijlstra F, Reiber JHC, Serruys PW. Does intracoronary papaverine dilate epicardial coronary arteries? Implications for the assessment of coronary flow reserve. Cathet Cardiovasc Diagn 1988;14:1-6.
42 De Bruyne B, Paulus WJ, Heyndrickx GR. Dynamic changes in transstenotic pressure gradient with intracoronary papaverine: an index of stenosis severity? Circulation 1991;84:II-65.

43 Milner P, Bodin P, Loesch A, Burnstock G. Rapid release of endothelin and ATP from isolated aortic endothelial cells exposed to increased flow. Biochem Biophys Res Commun 1990;170:649-56.

44 Davies MJ, Woolf N, Rowles PM, Pepper J. Morphology of the endothelium over atherosclerotic plaques in of the endothelium over atherosclerotic plaques in

45 Furchgott RF, Zawadzk JV. The obligatory role of endothelial cells in the relaxation of arterial smooth muscle by acetylcholine. Nature 1980;288:373-6.

46 Ludmer PL, Selwyn AP, Shook TL, et al. Paradoxical vasoconstriction induced by acetylcholine in atherosclerotic coronary arteries. $N$ Engl $f$ Med 1986;315: 1046-51.

47 Zeiher AM, Drexler $H$, Wollshlaeger $H$, Just $H$. Modulation of coronary vasomotor tone in humans. Progressive endothelial dysfunction with different early stages of atherosclerosis. Circulation 1991;83:391-401.

48 Werns SW, Walton JA, Hsia HH, Nabel EG, Sanz ML, Pitt B. Evidence of endothelial dysfunction in angiographically normal coronary arteries of patients with graphically normal coronary arteries of patients with
coronary artery disease. Circulation 1989;79:287-91.

49 Golino P, Piscione F, Willerson JT, et al. Divergent effects of serotonin on coronary artery dimensions and blood flow in patients with coronary atherosclerosis and control patients. $N$ Engl I Med 1991;324:641-8.

$50 \mathrm{McF}$ adden EP, Clarke JG, Davies GJ, et al. Effect of intracoronary serotonin on coronary vessels in patients with stable angina and patients with variant angina. $N$ Engl f Med 1991;324:648-54.

51 Bolton TB, Clapp LH. Endothelial-dependent relaxant actions of carbachol and substance $P$ in arterial smooth muscle. Br $\mathcal{F}$ Pharmacol 1986;87:713-23.

52 Holtz J, Forstermann U, Pohl U, Geisler M, Bassenge E. Flow-dependent, endothelium-mediated dilation of epicardial coronary arteries in conscious dogs: effects of cyclooxygenase inhibition. F Cardiovasc Pharmacol 1984: 6:1161-9.

53 Fischell TA, Bausbeck KN. Effects of luminal eccentricity on spontaneous coronary vasoconstriction after successful percutaneous transluminal coronary angioplasty. $\mathrm{Am}$ $千$ Cardiol 1991;68:530-4.

54 Vanhoutte PM. Vascular endothelium and $\mathrm{Ca}^{++}$antagonists. F Cardiovasc Pharmacol 1988;12(suppl 6):S21-8. 